\title{
The genera Typhula and Pistillaria (Typhulaceae, Aphyllophorales) in Finland. A check-list of the species
}

\author{
ANTON SHIRYAEV and HEIKKI KOTIRANTA
}

\begin{abstract}
SHIRYAEV, A. \& KOTIRANTA, H. 2007: The genera Typhula and Pistillaria (Aphyllophorales) in Finland. A check-list of the species. - Karstenia 47: 0-0. 2007. Helsinki. ISSN 0453-3402.
\end{abstract}

Twenty one Typhula (Pers.) Fr. species and one Pistillaria Fr. species are reported from Finland. Five species are new for the country, viz. Typhula capitata (Pat.) Berthier, T. culmigena (Mont. \& Fr.) J. Schröt., T. hyalina (Quél.) Berthier, T. spathulata (Peck) Berthier, and T. struthiopteridis Corner. Most of the species are common. The localities, habitats, substrates and short ecological notes for the new species are given.

Key words: Distribution, Finland, Pistillaria, Typhula.

Anton Shiryaev, Institute of Plant and Animal Ecology RAS, 8 March str. 202, 620144, Ekaterinburg, Russia.E-mail:26081978@mail.ru

Heikki Kotiranta, Finnish Environment Institute, Research Department, Research Programme for Biodiversity, P.O. Box 140, FI-00251 Helsinki, Finland. E-mail: heikki.kotiranta@ymparisto.fi

\section{Introduction}

Most of the 22 species of Typhula and Pistillaria found in Finland are saprotrophic, more seldom they are parasites of grasses and herbs. P. A. Karsten published several papers (e.g. Karsten $1879,1881 \mathrm{a}, 1881 \mathrm{~b}, 1881 \mathrm{c}, 1882,1899)$ on new species and notes on species which he mostly collected in the vicinity of Mustiala (Tammela). He did not give detailed information on the distribution of the species in Finland, because no other material was available for him. Some more recent papers also list Typhula species. Ulvinen et al. (1981) listed species from the province of Koillismaa (Ks), and Ohenoja (1996) from Lapland, and according to Knudsen (1997) 17 species were known in Finland. However, the distribution of most of the species was not given by Knudsen (1997).

\section{Material and methods}

This is the first study where the whole Finnish material, altogether 390 specimens, of Finnish and some other herbaria (H, OULU, TUR, SVER, TAA) was examined.

The biological provinces and collecting sites are according to Heikinheimo and Raatikainen (1981). The provinces are illustrated also in Hansen and Knudsen (1997: 28). The nomenclature of Typhulaceae follows Berthier (1976) and that of vascular plants Hämet-Ahti et al. (1998). The following abbreviations for substrates are used: Epilobium refers to E. angustifolium, Pinus to Pinus sylvestris, Picea to Picea abies, and Populus to Populus tremula. Species new to Finland are marked with an asterisk (*). Notes of the distribution, hosts and biology of the new species are partly based on Russian material, made by the senior author, and have not been published before. We believe that the biology of the species in Finland is very similar to that in adjacent areas in Russia. The identification of the species is made by the senior author. 


\section{List of species}

Pistillaria paradoxa (P. Karst.) Corner

EH: Tammela, Mustiala, decayed twigs of $P i-$ nus, 8.XIII.1865 Karsten 1297, 1298, 1300 (lectotype, H), decayed twigs of Pinus, 5.I.1866 Karsten 1299 (topotype, H).

\section{Typhula athyrii Remsberg}

Syn. Typhula todei Fr. : Fr.

EH: Tammela, Mustiala, Haarankorpi, dead petioles of Athyrium sp., 1.IX.1869 Karsten 3164 $(\mathrm{H})$.

*Typhula capitata (Pat.) Berthier

EH: Luhanka, Lempää, dead Calamagrostis arundinacea, 25.IV.2007 Shiryaev 7000 (SVER). InL: Utsjoki, Kevo, dead grasses, 30.VIII.1973 Ulvinen (OULU F23311).

\section{Typhula caricina P. Karst.}

EH: Tammela, Haarankorpi, Carex vesicaria, 16.IX.1869 Karsten 1291 (lectotype, H), Tammela, Mustiala, C. vesicaria, 8.IX.1870 Karsten 1292 (syntype, H). PH: Virrat, Hauhuu, Sikosaari, Salmela, decaying leaves of Carex sp., 27.IX.1995 Kytövuori 95-1599(H).

\section{Typhula crassipes Fuckel}

Syn. T. corallina Quél. \& Pat.

V: Turku, Impivaara, decaying leaves of Populus, 20.IX.1981 Huhtinen 81/226 (TUR 68946).

EH: Nokia, Kankaantaka, decaying leaves of Betula pendula and Populus, 18.IX.1977 E. Ohenoja (OULU F49269), Tammela, Haarankorpi, decaying leaves of Populus, 2.IX.1869 Karsten (H), Tammela, Mustiala, decaying leaves of $\mathrm{Al}$ nus sp., 20.X.1891 Karsten 1286 (holotype of $T$. cylindracea P. Karst., H). OP: Muhos, Muhosperä, Isterinkoski, dead grasses, 4.VII.1970 E. \& M. Ohenoja (OULU F49293). Ks: Kuusamo, decaying stems of Actaea spicata, 29.VIII.1988 Ulvinen (OULU F22652).

*Typhula culmigena (Mont. \& Fr.) J. Schröt. V: Korppoo, Bonäs, dead stem of Verbascum thapsus, 17.VII.1948 Kari (TUR 30810). U: Nurmijärvi, church village, dead stems of Festuca pratensis, 29.IX.1986 Askola 1902 (TUR 53340). EK: Sippola, Ruotila, Epilobium, 7.IX.1947 Kujala (TUR 062431). EH: Padasjoki, Vesijako Strict Nat. Res., fallen stems of
Epilobium, 13.IX.2001 Parmasto (TAA(M) 180732). Tammela, Mustiala, decaying grasses, 2.VII.1867 Karsten (H). OP: Oulu, Nuottasaari, Equisetum arvense, 7.X.1965 Ulvinen (OULU F49288). Pudasjärvi, Jaurakkajärvi, dead stems of Epilobium, 18.VII.1988 E. Ohenoja (OULU F45805); Ks: Kuusamo, Liikasenvaara, Korvasvaara, spruce dominated herb-rich forest, Epilobium, 23.VIII.1978 E. Ohenoja (OULU F49299).

Typhula erythropus (Pers. : Fr.) Fr.

V: Lohja, Orsnäs, decaying leaves of Salix caprea, 1.X.1937 Laurila (H). Parainen, Degerholm, decaying leaves, 8.X.1967 A. \& K. Pohjola (TUR 30812). Turku, Hirvensalo, leaves of Populus, 20.IX.1983 Huhtinen 83/317 (TUR 73707). St: Noormarkku, decaying leaves of Alnus incana, 20.IX.1937 Laurila (H, TUR 30644). EH: Lammi, decaying petioles of deciduous trees, 18.IX.1990 E. Ohenoja (OULU F34126). Luhanka, Lempää, decaying leaves of Populus, 24.IV.2007 Shiryaev 7001 (SVER). Tammela, decaying leaves of Acer platanoides, 15.VIII.1868 Karsten (H). Tammela, Haarankorpi, deciduous leaves, 24.IX.1878 Karsten $(\mathrm{H})$. Tampere, Peltolammi, decaying leaves of $\mathrm{Al}$ nus sp., 9.IX. 1988 Söderholm (H). Tampere, Rusko, Polunmäki, dead petioles of Alnus sp., 18.IX.2005 Söderholm 3669 (TUR 173242). EP: Isojoki, Lauhanvuori, Huhtakorpi, mesic coniferous forest, leaves of $A$. incana, 21.X.2005 E. Ohenoja (H). Kn: Paltamo, Oikarila, deciduous litter, 22.IX.1974 E. \& M. Ohenoja (OULU F38685). OP: Kiiminki, Kalkkialue, Vasikkasuo, decaying leaves of Betula sp., 23.IX.1969 Ulvinen (OULU F49317).

\section{Typhula graminum P. Karst.}

EH: Luhanka, Lempää, decaying Calamagrostis arundinacea, 24.IV.2007 Shiryaev 7002, 7003 (SVER). Tammela, Mustiala, X.1867 Karsten (H, holotype);

*Typhula hyalina (Quél.) Berthier

EH: Tammela, Mustiala, dead stems of Dactylis glomerata, 18.VIII.1869 Karsten (H), meadow, dead stems of Carex sp., 21.IX.1869 Karsten (H).

Typhula incarnata Lasch ex Fr. Syn. T. elegantula P. Karst. 
EH: Luhanka, Lempää, decaying leaves of $\mathrm{Ca}$ lamagrostis arundinacea, 23.IV.2007 Shiryaev 7004 (SVER). Tammela, Mustiala, Elytrigia repens, VIII.1868 Karsten 1294, 1295 (isotype of T. elegantula, H), Calamagrostis sp., 6.X.1867 Karsten 1477, 1478 (H). PS: Kiuruvesi, Mäenpää, Secale cereale, 9.V.1948 Huttunen (H). Maaninka, Festuca pratensis, 15.V.1948 Jamalainen $(\mathrm{H})$. OP: Oulu, Hintta, decaying grasses, 2.X.1975 E .Ohenoja (OULU F49351). Ylistaro, Phleum pratense, 5.VI.1946 Jamalainen (H).

According to Jamalainen (1957) and Mäkelä and Mäki (1980) T. incarnata is frequent in some years on cultivated winter cereals. However, the herbarium material is scanty.

\section{Typhula ishikariensis Imai var. ishikariensis}

ES: Mikkeli, Secale cereale, 3.V.1948 Ylimäki (H), Mikkeli Agr. Stat., Secale cereale, 29.IV.1948 Koskinen (H). Savonlinna, Nojanmaa, grasses, 1947 Ylimäki (H). PH: Karstula, Vastinki, Phleum pratense, 1.V.1948 Marttinen (H). KP: Ruukki, Secale cereale, 31.V.1946, 3.VI.1946, 31.VI.1946 Jamalainen (H). PeP: Rovaniemi, Apukka, decaying grasses, 11.V.2000 Piippa Wäli (TUR 159943). KiL: Kolari, Phleum pratense, 7.VI.1946 Jamalainen $(\mathrm{H})$.

\section{Typhula lutescens Boud.}

PH: Keuruu, Pihlajavesi, decaying Equisetum sp., 28.IX.1995 Kytövuori 95-1664 (H). Kn: Puolanka, Paljakka, Jatkonsuo, decaying herbs and mosses, 7.IX.1979 Eurola (OULU F49274). OP: Kiiminki, Isohalmeenmaa, decaying Equisetum sp., 5.IX.1968 M. Ohenoja (OULU F49307). Kiiminki, limestone area, Equisetum, 23.IX.1969 Ulvinen (OULU F49308), Raivio spring, calcareous soil, E. palustre, 5.IX.1968 Ulvinen (OULU F49306). PeP: Tervola, Peura, Equisetum sp., 3.IX.1970 M. Ohenoja (OULU F49310). InL: Utsjoki, Kevo, E. fluviatile, 30.VIII.1973 Ulvinen (OULU F23320). Utsjoki, Njallajärvi, mosses and decaying herbs, 13.IX.1967 Kankainen (TUR 30815).

Typhula micans (Pers. : Fr.) Berthier

Syn. T. anceps P. Karsten

V: Kakskerta, Harjattula ön, Trifolium montanum, 17.VIII.1936 Kari (TUR 72321); St: Tyrvää (Tyrvis), decaying Cirsium arvense, 14.IX.1859 Karsten 1289 (H); EH: Kangasala,
Vihtinen, decaying leaves of Angelica sylvestris, 07.VIII.1994 Söderholm 2229 (TUR 113330), Luhanka, Lempää, dead stems of Tussilago farfara, 25.IV.2007 Shiryaev 7005, 7006 (SVER), Tammela, Mustiala, decaying leaves of Salix sp., 14.IX.1870 Karsten 1285 (holotype of T. anceps, H), decaying Cirsium arvense, 30.VI.1871 Karsten 1290 (H), Sedum acre, 23.IX.1872 Karsten $1306(\mathrm{H})$.

Unlike Berthier (1976) and Knudsen (1997), we believe that $T$. anceps is a synonym of $T$. $m i$ cans, because we could not found reliable distinguishing characteristics between these species.

Typhula phacorrhiza (Reichard : Fr.) Fr.

V: Koski, Hongisto, litter in mixed forest, 30.IX.1990 Heinonen 99-90 (TUR 101595). Kustavi, Kiparluoto, Riihivainio, decaying leaves and other plant remnants, 25.IX.1994 Mäkinen 94-1124 (TUR 114336). Turku, dead leaves of Betula sp., 17.X.1993 Vauras 9021 (TUR 109955), compost heap,17.X.2006 Vauras 25584 F (TUR 176466). U: Nurmijärvi, church village, litter, 15.IX.1986 Askola $2022(\mathrm{H})$, deciduous litter, 22.IX.1990 Askola 2735 (H). Sipoo, Hindsby, decaying leaves of Populus, 23.09.1978 Saarenoksa 32578 (H). St: Noormarkku, decaying leaves of Betula and Alnus sp., 18.IX.1937 Laurila (TUR 30785). EH: Kalvola, TaljalaNiemi, Kalliomaa Nat. Res., decaying leaves, 23.IX.1980 Alho (TUR 97507). Lammi, Hauhiala, litter, 3.IX.1984 Harmaja (H), Pappilankylä, decaying leaves of Populus, 7.IX.1983 Harmaja (H). Tammela, decaying leaves of $B$. pendula, 1.V.1972 E. Ohenoja (OULU F49272). Tampere, Peltolammi, deciduous litter, 31.VIII.1988 Söderholm 1513 (OULU F49315). OP: Kiiminki, Murtoinsaaret, deciduous litter, 5.IX.1968 Ulvinen (OULU F49345), 8.IX.1968 M. Ohenoja (OULU F49352). Muhos, Muhosperä, deciduous litter, 17.IX.1976 E. Ohenoja (OULU F49349).

Typhula quisquiliaris (Fr. : Fr.) Henn.

U: Kirkkonummi, mixed forest, with Corylus, Picea, Populus, Sorbus, decaying petioles of Pteridium aquilinum, 25.08.1982 Saarenoksa 46282 (H). EH: Kangasala, Vatiala, Kisapirtti, dead petioles and leaves of $P$. aquilinum, 29.VIII.1995 Söderholm 2439 (TUR 115285). Tammela, Mustiala, P. aquilinum, VIII.1866 Karsten (H). KP: Siikajoki, Paavola, decaying petioles of $P$. aquilinum 29.VIII.1965 Kankainen (TUR 97944). 
Typhula sclerotioides (Pers.) Fr.

V: Merimasku, decaying herbs, VIII.1860 Karsten 1803 (H). U: Espoo, decaying grasses, IX.1937 Frey (H). EH: Tammela, Mustiala, herbs, VIII.1865 Karsten (H). Kn: Paltamo, Oikarila, deciduous litter, 22.IX.1974 E. \& M. Ohenoja (OULU F49344). Sotkamo, Kontinjoki, Lauttolampi, decaying leaves of Populus, 10.IX.1986 Ulvinen (OULU F49275). OP: Oulu, Toppila, Eteläsatama, deciduous litter, 1.X.1965 Ulvinen (OULU F49346). Ks: Posio, Livojärvi, herb-rich forest, decaying leaves of Prunus padus, 28.IX.1982 Ulvinen (OULU F49350). InL: Utsjoki, Tsharsjoki, delta island, decaying leaves of Betula sp. and Salix lanata, 15.VIII.1962 Kankainen (TUR 28665).

\section{Typhula setipes (Grev.) Berthier}

Syn. T. gyrans Fr., T. ovata P. Karst., T. pusilla Fr.

V: Turku, Yliopistonmäki, decaying herbs, 11.X.1999 Huhtinen 88/110 (TUR 127939). U: Helsinki, leaves of Salix fragilis, autumn 18?? Karsten 1304 (H). St: Noormarkku, Poosjoki, decaying leaves of Populus, 25.IX.1937 Laurila (H). EH: Tammela, Mustiala, decaying leaves of Betula sp., 22.X.1868 Karsten 1479 (H), leaves of Salix viminalis, 20.X.1891 Karsten 1480 (H). Tampere, Koivistonkylä, decaying leaves of Betula sp., 6.X.1987 Söderholm 1476 (H). KP: Pietarsaari (Jakobstad), decaying leaves of Populus, 21.X.1862 Karsten 1301 (H). OP: Muhos, Leppiniemi, dead leaves of Prunus padus, 29.X.1974 E. Ohenoja (OULU F49291). Oulu, Korkeasaari, decaying leaves of Alnus sp., 19.X.1969 Ulvinen (OULU F49287), Orikari, beach, decaying leaves of Alnus sp., 24.IX.1965 Ulvinen (OULU F49289, 49290).

*Typhula spathulata (Peck) Berthier

Syn. T. fruticum P. Karst.

OP: Oulu, decaying petioles and stems of Rubus idaeus, 5.X.1965 Ulvinen (OULU F49285).

The type material of $T$. fruticum is missing from $\mathrm{H}$.

\section{*Typhula struthiopteridis Corner}

St: Kankaapää, Venesjärvi, Sinahmi, on decaying petioles of Matteuccia struthiopteris, 1.IX.1936 Laurila (TUR 30807, 30811). EH: Tammela, Haarankorpi, dead petioles of $M$. struthiopteris, 1.IX.1869 Karsten (H).
Typhula cf. subvariabilis Berthier

OP: Muhos, Muhosperä, Pekkala, dry herb-rich forest among mosses, 14.VIII.1968 M. Ohenoja (OULU F49296). KiL: Kittilä, Aakenus, Homevuotso Forest Res., old herb-rich spruce forest, decaying leaves of Sorbus aucuparia, 12.IX.1983 Ulvinen (OULU F49303).

Typhula uncialis (Grev.) Berthier

Syn. Clavaria typhuloides Peck, Pistillaria petasitites Imai

If otherwise not stated, the substrate is decaying stem of Epilobium angustifolium.

V: Koski, Halikkola, 5.VII.2000 M-L. \& P. Heinonen 567-2000 (TUR 136891). Koski, Hongisto, 8.VII.1990 Heinonen 27-90 (TUR 101269), 31.VII.1993 Heinonen 61-93 F (TUR 112433). Paimio, Kruuvainen, 22.VII.2002 M-L. \& P. Heinonen 16-2002 (TUR 160278). Parainen, Kirjalaön, Trollgärda, 2.IX.2005 M-L. \& P. Heinonen 108-2005 (TUR 174325). Särkisalo, Förby, 23.IX.1994 Huhtinen (TUR 111165). EK: Sippola, Ruotila, 19.VII.1947 Kujala (OULU F49268). EH: Kangasala, Lehtola, 27.VII.2006 Söderholm 3721 (TUR 178523). Korpilahti, Oittila, 20.VIII.1986 Ulvinen (OULU F49327). Luhanka, Lempää, 25.IV.2007 Shiryaev 7008 (SVER). Pälkäne, Mallasvesi, 18.VIII.1993 Kytövuori 93-292 (H). Sysmä, Onkiniemi, Uotila, Epilobium sp., 11.VIII.1987 Haikonen 8730 (H). Tammela, Mustiala, 4.IX.1867 Karsten $1288(\mathrm{H}), 10 . X .1881$ Karsten $1476(\mathrm{H})$. Tampere, Kaukajärvi, Selkämäki, 31.VII.1976 Söderholm 147 (H), Rusko, 28.VII.1985 Söderholm 1202 (TUR 80222). ES: Kangasniemi, 18.IX.2004 Jakobson 4310 (H). Rantasalmi, Kolkonpää, 8.VIII.1998 Huhtinen 98/60 (TUR 124413); EP: Vimpeli, Moskovankallio, Epilobium sp., 18.VIII.1993 Jakobson (H); PH: Äänekoski, Parantala. Aittoniemi, 17.VII.1981 Storbacka (OULU F49273). PS: Heinävesi, Vihtari, Lehtomäki, Epilobium sp., 12.VIII.2003 Haikonen 22697 (H). Lapinlahti, Haminanharju, 17.VIII.1971 Pohjola 71-528 (TUR 76489). PK: Ilomantsi, Mekrijärvi, 26.VIII.1996 M-L. \& P. Heinonen 68-96 (TUR 116902). KP: Haapavesi, Mieluskylä, VIII.1970 Koskela (OULU F49333). OP: Kiiminki, 19.VIII.1967 Ulvinen (OULU F49337), limestone area, 4.X.1966 Ulvinen (OULU F49332). PeP: Kemi, Ajos, 19.VIII.1986 Kamula (OULU F49294). Rovaniemi, Jaatila, 17.VIII.1999 E. Ohenoja (OULU 
F46574). Rovaniemi, Tennilä, Vieno Viiri, 22.VII.1981 E. Ohenoja (OULU F49301). InL: Utsjoki, 25.VIII.1964 Mäkinen (TUR 71527). Russia. Murmansk Region. Ks: Salla, Kisajoki, 22.VII.1937 Laurila (H).

\section{Typhula variabilis Riess}

U: Helsinki, Käpylä, decaying leaves of Acer platanoides, 15.XII.2002 Shiryaev 7009 (SVER). EH: Vilppula, Keuruu, Ukonselkä lake, decaying Equisetum fluviatile, 30.VII.1999 Järvinen 1641 (TUR 131531). OP: Kiiminki, Pöksälänkangas, deciduous litter, 22.IX.1968 M. Ohenoja (OULU F49347). Oulu, Hupisaaret, decaying leaves of Prunus padus, 29.IX.1965 Ulvinen (OULU F49343, TUR 30746). Ks: Kuusamo, Oulanka, Liikasenvaara, rich brook-side forest, litter of Betula and Salix, 24.VIII.1978 Ulvinen (OULU F49321). InL: Utsjoki, Kevo, deciduous litter, 28.VIII.1973 Ulvinen (OULU F23322).

\section{Notes on some species}

Knudsen (1997) reports two species, viz. Typhula muelleri (Sauter) Corner and Typhula trifolii Rostrup to occur in Finland, but because no herbarium material of them was available, we could not confirm their existence in Finland. According to Knudsen (1997), T. sclerotioides sensu Karsten (1882) is T. muelleri. Karsten (1882) reports $T$. sclerotioides to occur in Norway on Gentiana purpurea, which does not belong to the flora of Finland.

All the species new for Finland are known also in adjacent areas in Russia (Archangel Region, Murmansk Region, Leningrad Region and Karelian Republic) and the notes of their ecology are largely based on that data. It must be noted that many of the species range also much further to the south (even semi-deserts), but here only the biological requirements in boreal zone and subarctic or subalpine areas are described.

\section{Typhula capitata}

A common boreal species with a holarctic distribution. It grows from hemiboreal zone in the south to the subarctic/subalpine areas in the north up to the Barents sea but is rare in the north. Its habitat requirements are not especially strict, but mostly it has been collected from southwestern slopes (on Alopecurus, Calamagrostis) or an- thropogenic sites (on Deschampsia). It prefers wet, open habitats close to rivers or lake shores, and has not been found inside coniferous forests. Fruiting time in hemiboreal zone is October, and in more northern areas from mid-August to the first frosts.

\section{Typhula culmigena}

A common boreal species with a holarctic distribution. It grows from hemiboreal zone in the south to subarctic/subalpine areas in the north, where it is not as common as in the boreal zones. It prefers open, sunny sites, like coasts, meadows, road sides etc., and has a very wide range of substrates, if compared with the closely related T. uncialis, which almost exclusively grows on Epilobium. Typhula culmigena has been found from herbs and grasses like Actaea, Angelica, Cicerbita, Dactylis, Epilobium, Heracleum, Festuca and Secale and on dead leaves of Alnus, Betula and Populus. Fruitbodies can be found from spring to the first snow cover.

\section{Typhula hyalina}

A common boreal species, known only in Eurasia. It is widely distributed from hemiboreal zone to subarctic areas, where it has, however, been found only twice from Carex species. In subalpine area in Murmansk region on Khibiny Mountains (Gory Hibiny) it grows on Carex spp. and Juncus spp. but is not common. In boreal Pinus forests it prefers Melica nutans, and in Picea forests Carex spp., Juncus spp. and Dactylis glomerata. The fruiting period in south boreal-north boreal zones is from late August to the first snow cover. In hemiboreal forests it infests Allium, Bromus, Dactylis, Carex, Melica and Juncus in wet localities. The fruiting starts in the beginning of October.

\section{Typhula spathulata}

A common species from temperate zone to subarctic areas, but is more common in the south. In hemiboreal zone $T$. spathulata grows on twigs of several deciduous trees and bushes, like Acer platanoides, Alnus glutinosa, A. incana, Cytisus, Salix spp., Syringa spp., Quercus robur, Ulmus spp. and Rubus idaeus. It favors western and north-western, somewhat moist slopes and the substrate is not covered by decaying leaves. The fruiting period is from the mid-September to the mid-October. 
In southern boreal to northern boreal zones $T$. spathulata prefers twigs of Alnus spp., Prunus padus, Salix spp. and Rubus idaeus, but is never collected from Populus, Betula spp. or Tilia cordata. The habitats are moist slopes, hill tops and openings in coniferous forests. The fruiting period begins at the end of August and continues till the middle of September.

In subarctic areas $T$. spathulata is rare, but grows on Alnus incana, Salix spp. and Rubus idaeus. It prefers shady northern or north-western slopes and grows sometimes under leaf litter. It has never been collected from bogs or permanently wet habitats. The fruiting period is short, from the middle to the end of August.

\section{Typhula struthiopteridis}

A common boreal species, and known at least from Estonia, European part of Russia, Ural Mountains, the Caucasus, and Siberia. In eastern Fennoscandia collected from hemiboreal and southern boreal zones exclusively from dead petioles of Matteuccia struthiopteris.

In hemiboreal zone it prefers humid hill tops, and is never found close to water courses. In this zone it is also more frequent than in the north and the fruitbodies are larger. From southern boreal zone northwards the habitats are normally coniferous forests, less often deciduous forests, and it is very rare along brook-sides or lake shores. Fruiting period begins at the end of August and continues till the first frosts.

Acknowledgements: The curators of the following herbaria, H, TUR, TAA, SVER, OULU, and Esteri Ohenoja (Oulu), are warmly thanked for the loans, as well as the staff especially in the Botanical Museum, University of Helsinki, for the kind help for the senior author during his visit. The author Kotiranta thanks the Ministry of Environment for a research grant (PUTTE, YM131/5512/2002).

\section{References}

Berthier, J. 1976: Monographie des Typhula Fr., Pistillaria Fr. et genres voisins. - Bull. Mens. Soc. Linn. Lyon 45: 1-233.

Hämet-Ahti, L., Suominen, J., Ulvinen, T. \& Uotila, P. (eds.) 1998: Retkeilykasvio. - Finnish Mus. Nat. Hist., Bot. Mus., Helsinki. 656 pp. (In Finnish).

Hansen, L. \& Knudsen, H. (eds.) 1997: Nordic acromycetes 3. Heterobasidioid, aphyllophoroid and gastromycetoid Basidiomycetes. - Nordsvamp, Copenhagen. $444 \mathrm{pp}$.

Heikinheimo, O. \& Raatikainen, M. 1981: Ruutukoordinaattien ja paikannimien käyttö Suomessa. (Grid reference and names of localities in the recording of biological finds in Finland.) - Notulae Entomol. 61: 133-154.

Jamalainen, E. A. 1957: Overvintering of Gramineaeplants and parasitic fungi II. On the Typhula sp. fungi in Finland. - J. Sci. Agric. Soc. Finland 29: 75-81.

Karsten, P. A. 1879: Symbolae ad Mycologiam Fennicam 6. Basidiomycetes De B. - Medd. Soc. Fauna Flora Fennica 5: 15-46.

Karsten, P. A. 1881a: Fungi novi, lecti atqve descripti a P. A. Karsten. - Hedwigia 20: 177-179.

Karsten, P. A. 1881b: Hymenomycetes Fennici. - Acta Soc. Fauna Flora Fennica 2(1): 1-40.

Karsten, P. A. 1881c: Enumeratio Boletinearum et Polyporearum Fennicarum, systemate novo dispositarum. - Rev. Mycol. 3(9): 16-19.

Karsten, P. A. 1882: Rysslands, Finlands och den Skandinaviska Halföns hattsvampar 2. Pip-, tagg-, hud-, klubb- och gelésvampar. - Bidrag Känned. Finlands Natur Folk 37(9): 1-257.

Karsten, P. A. 1899: Finlands basidsvampar. Floristiska handböcker för nybegynnare. - Soc. Fauna Flora Fennica, Helsingfors Centraltryckeri. Helsingfors. 186 pp., 9 pls.

Knudsen, H. 1997: Typhulaceae Jülich. - In: Hansen, L. \& Knudsen, H. (eds.), Nordic macromycetes 3. Heterobasidioid, aphyllophoroid and gastromycetoid Basidiomycetes, 256-260. Nordsvamp, Copenhagen.

Mäkelä, K. \& Mäki, L. 1980: The occurrence of micromycoglora in the stem base and roots of cereals in southern Finland. - Ann. Agric. Fenniae 19: 87-222.

Ohenoja, E. 1996: A check-list of the larger fungi in Inari Lapland (NE Finland) and in Finnmark (NE Norway). - Kevo Notes. 11: 1-26.

Ulvinen, T., Ohenoja, E., Ahti, T. \& Alanko, P. 1981: A check-list of the fungi (incl. lichens) of the Koillismaa (Kuusamo) biological province, N.E. Finland. - Oulanka Reports 2: 1-64. 